Errata

Classification of Lactobacillus divergens, Lactobacillus piscicola, and some catalasenegative, asporogenous, rod-shaped bacteria from poultry in a new genus, Carnobacterium

M. D. Collins, J. A. E. Farrow, B. A. Phillips, S. Feresu and D. Jones

International Journal of Systematic Bacteriology (1987), 37, part 4, pp. 310-316

The name of the fourth author was spelled incorrectly as S. Ferusu. The correct spelling is S. Feresu.

\title{
Validation of the publication of new names and new combinations previously effectively published outside the IJSB. List no. 29
}

International Journal of Systematic Bacteriology (1989), 39, part 2, pp. 205-206

The page numbers given for the paper that included the effective publication of the name Pseudonocardiaceae (pp. 16-19) are incorrect. The correct reference is:

Embley, M. T., Smida, J. \& Stackebrandt, E. (1988). The phylogeny of mycolate-less wall chemotype IV actinomycetes and description of Pseudonocardiaceae fam. nov. Syst Appl Microbiol 11, 44-52.

Chitinophaga ginsengisegetis sp. nov. and Chitinophaga ginsengisoli sp. nov., isolated from soil of a ginseng field in South Korea

H.-G. Lee, D.-S. An, W.-T. Im, O.-M. Liu, J.-R. Na, D. H. Cho, C. W. Jin, S.-T. Lee and D.-C. Yang

International Journal of Systematic and Evolutionary Microbiology (2007), 57, part 7, pp. 1396-1401

The DSMZ accession number for the type strain of Chitinophaga ginsengisoli sp. nov. is DSM $18107^{\mathrm{T}}$ and not DSM $18017^{\mathrm{T}}$ as given in the abstract and species description. 